\title{
Seasonal Changes in the Tropical Atlantic Circulation: Observation and Simulation of the Guinea Dome
}

\author{
Gerold Siedler, Norbert Zangenberg, and Reiner ONken
}

Institut für Meereskunde, an der Universität Kiel, Kiel, Germany

\author{
Alain Morlière \\ Institut Français de Recherche Scientifique Pour le Développement en Coopération (ORSTOM) \\ and Laboratoire d'Océanographie Dynamique et de Climatologie \\ Université Pierre et Marie Curie, Paris
}

\begin{abstract}
The Guinea Dome is a permanent, quasi-stationary feature on the eastern side of the thermal ridge extending zonally across the tropical North Atlantic. The dome is a part of the large-scale near-surface flow fields associated with the North Equatorial Current, the North Equatorial Countercurrent and the North Equatorial Undercurrent. In the present study, historical and recently obtained hydrographic data are combined to investigate the thermohaline structure and geostrophic flow field in the vicinity of the dome. It is shown that the Guinea Dome exists throughout the year both in subthermocline and thermocline layers, that it has a corresponding cyclonic geostrophic flow, and that seasonal changes occur with respect to its vertical structure, horizontal extent, and position. The observational results are then compared with simulations from a general circulation model of the tropical Atlantic. A seven-year simulation forced by observed monthly winds is run to compute a monthly climatology. The model adequately simulates the Guinea Dome with respect to its structure, flow field, and seasonal variability.
\end{abstract}

\section{INTRODUCTION}

In his review on thermal domes in the eastern extensions of equatorial current systems, Voituriez [1981] described three such domes which are evident in observational data. They are all characterized by upward displacements of isotherms in the thermocline layer down to depths of more than $300 \mathrm{~m}$. Figure 1 shows the approximate positions of the three domes: the Guinea dome in the tropical North Atlantic [Rossignol and Meyruis, 1964; Voituriez and Herbland, 1982; Hagen and Schemainda, 1984], the Angola dome in the South Atlantic [Mazeika, 1968], and the Costa Rica dome in the North Pacific [Wyrtki, 1964]. Also shown in Figure 1 is an analogous "Peru dome" in the South Pacific, one that might be anticipated near $8^{\circ} \mathrm{S}, 85^{\circ} \mathrm{W}$ on the basis of wind stress, water mass, and current fields, but one which has yet to be identified. In the North Pacific, Wyrtki [1964] found the Costa Rica dome to be a permanent feature at the eastern end of the thermocline ridge extending along the northern flank of the North Equatorial Countercurrent (NECC). It has remained unclear, however, as to whether or not its Atlantic counterpart, the Guinea dome, is permanent as well.

The topography of mean geopotential anomaly for the tropical Atlantic is reproduced in Figure 2 [Merle and Arnault, 1985]. Zonal ridges and troughs are recognized which tend to become increasingly separated from the equator toward the east. The two thermal domes of the Atlantic are found in the eastern portions of the north and the south equatorial troughs. The lower thermocline waters in these domes originate in the west and are transported to the east by equatorial undercurrents.

It was first noted in the Pacific [Tsuchiya, 1975, 1981] that

Copyright 1992 by the American Geophysical Union.

Paper number 91JC02501.

0148-0227/92/91JC-02501\$05.00 an eastward undercurrent exists beneath the North Equatorial Countercurrent: the North Equatorial Undercurrent (NEUC). Extrema in water mass properties, in particular an oxygen maximum, can be followed along this deeper undercurrent as it branches away from the equator toward the east. Similar undercurrents have been identified in the tropical Atlantic by an oxygen maximum on the $26.65 \sigma_{t}$ surface [Hisard et al., 1976] and by Cochrane et al. [1979]. The two branches, the North and South Equatorial undercurrents (NEUC, SEUC) are found in the eastern Atlantic at $4^{\circ}-5^{\circ} \mathrm{N}$ and $4^{\circ}-5^{\circ} \mathrm{S}$, respectively. These can be seen in Figure 3, which is a meridional section of directly measured zonal velocity [from Bubnov and Egorikhin, 1979]. While the SEUC core is well separated from the South Equatorial Current (SEC) and Equatorial Undercurrent (EUC) in this section, the NEUC is not seen as a distinct current core separated from the NECC and is best identified by its water mass properties.

McPhaden [1984] has proposed that the strong nonlinearities in equatorial dynamics could be a reason for the detachment of the NEUC and SEUC from the EUC. The near-surface eastward pressure gradient reverses near the eastern boundaries, and a corresponding increase in westward pressure gradients at depths would push the undercurrents away from the equator. The thermal domes are found in the cyclonic flow out of the NEUC and SEUC, as is shown in Figure 4 [after Voituriez and Herbland, 1982].

The structure and temporal variability of the thermal domes, geopotential anomaly, and cyclonic geostrophic flow in the tropical Atlantic are not well known, and equatorial circulation models have not provided good simulations of them. Indications of such domes, however, have been obtained with earlier models. Busalacchi and Picaut [1983] ran a linear model on the equatorial $\beta$ plane with a single baroclinic mode following the approach used in the Pacific 


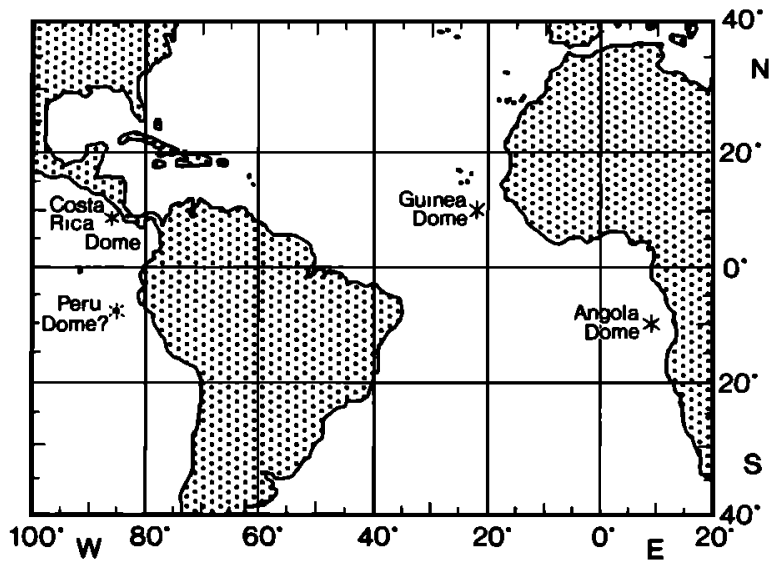

Fig. 1. Approximate locations of thermal domes in the tropical Atlantic and Pacific oceans. A "Peru dome," analogous to the Angola dome, has not yet been observed.

by Busalacchi and O'Brien [1980]. The single mode was justified by results from Philander and Pacanowski [1980], who found that in the case of a shallow tropical pycnocline the momentum transfer from wind stress will go predominantly into the second baroclinic mode. The wind fields from Hastenrath and Lamb [1977] used to force this model indicate that both the zonal and meridional annual mean wind stresses are small in the vicinity of the Guinea dome, suggesting that wind stress forcing outside this region may be important. Busalacchi and Picaut [1983], in studying the seasonal response of the ocean, found that the seasonal pycnocline displacements near the location of the Guinea Dome are small when compared with those in regions to the west and southeast. Shown in Figure 5 are the amplitudes and phases of the annual cycle in pycnocline depth obtained from their model. Referring to the upper panel, it is seen that a southwest-northeast oriented cell of low seasonal variability is centered near $12^{\circ} \mathrm{N}, 25^{\circ} \mathrm{W}$. This region of weak variability is about $1500 \mathrm{~km}$ long and $600 \mathrm{~km}$ wide. Busalacchi and Picaut concluded that the Guinea dome is nearly stationary, which they attributed to a balance between Ekman pumping in the north and Rossby wave contributions in the south that are out of phase with similar amplitudes.

Du Penhoat and Treguier [1984, 1985] formulated a continuously stratified model forced by the Hellerman and Rosenstein [1983] wind stress climatology in which the

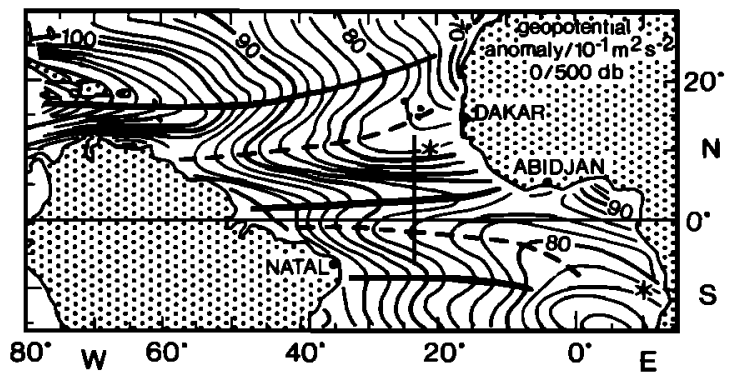

Fig. 2. Annual mean of geopotential anomaly (dynamic height) at the sea surface relative to $500 \mathrm{dbar}$ [after Merle and Arnault, 1985]. Heavy solid lines indicate ridges, and dashed lines indicate troughs. The meridional line at $23.5^{\circ} \mathrm{W}$ gives the location of the section presented in Figure 3. The approximate positions of the Guinea and Angola domes are indicated by asterisks.

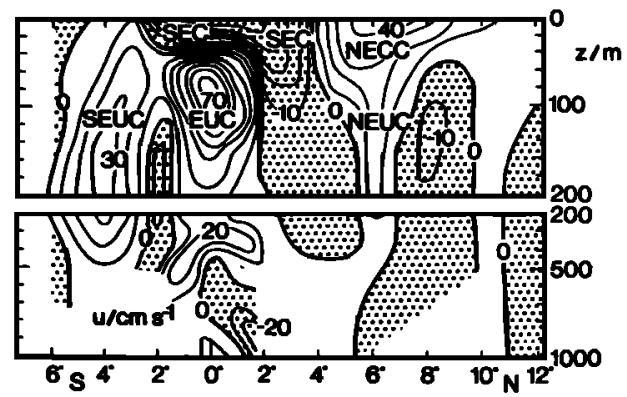

Fig. 3. Zonal current $u$ observed with moored instruments along $23.5^{\circ} \mathrm{W}$ in June-September 1974 [after Bubnov and Ekorikhin, 1979]. The surface currents and undercurrents are indicated as follows: NECC, North Equatorial Countercurrent; SEC, South Equatorial Current; NEUC, North Equatorial Undercurrent; EUC, Equatorial Undercurrent; SEUC, South Equatorial Undercurrent. Stippled areas indicate westward flow.

vertical structure resulted from the superposition of several normal modes. After a 3-year integration, the time-varying geopotential anomaly field relative to $500 \mathrm{dbar}$ was obtained. In Figure 6 we reproduce Du Penhoat and Treguier's fields of the annual mean resulting from all the variability and the amplitude of the annual cycle. In the annual mean topography, one finds a region with two minima in geopotential anomaly consistent with cyclonic motion. The eastern minimum corresponds in position and horizontal extent reasonably well with results we obtain in the following; however, their model-produced geopotential anomaly gradients are much smaller than those we find with actual observations. With respect to the seasonal amplitude map (bottom panel of Figure 6), there is a cell of small magnitude in the Guinea dome area along $8^{\circ} \mathrm{N}$ which bends to the northeast.

Philander and Pacanowski [1986] employed a multilevel primitive-equation model for the tropical Atlantic incorporating realistic bottom topography driven by the Hellerman and Rosenstein [1983] climatological winds. Their model results, after 2 years of integration, clearly show a strong local response in the western tropical Atlantic and a nonlocal response in the east. This is consistent with earlier model results from Busalacchi and $O^{\prime}$ Brien [1980], who found wave

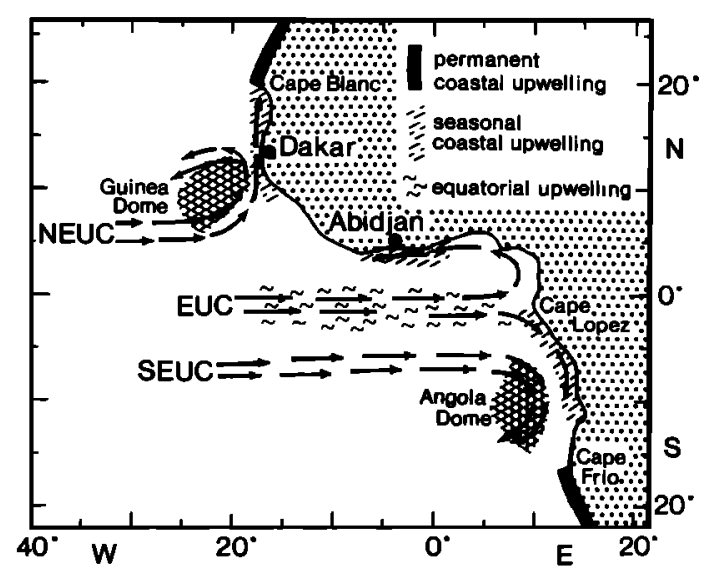

Fig. 4. Schematic presentation of the undercurrents in the equatorial Atlantic and their relation to the Guinea and Angola domes [after Voituriez and Herbland, 1982]. NEUC, North Equatorial Undercurrent; EUC, Equatorial Undercurrent; SEUC, South Equatorial Undercurrent. 

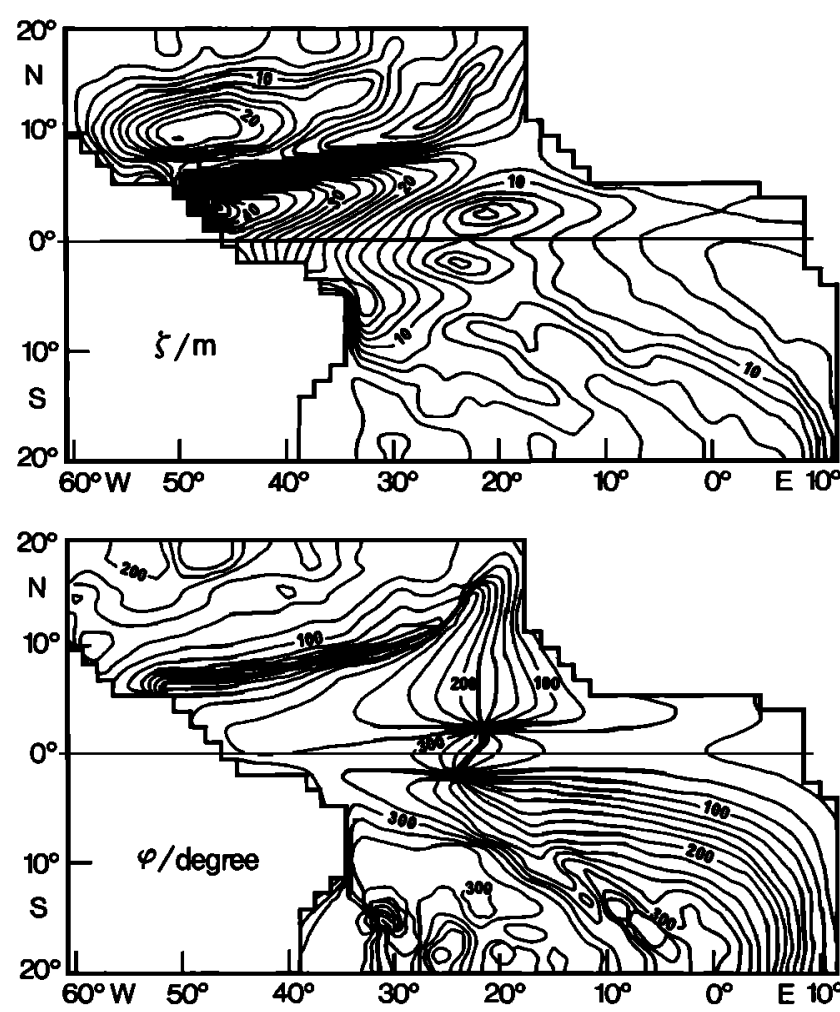

Fig. 5. Amplitude $\zeta$ and phase $\varphi$ of the annual cycle in pycnocline depth after the model of Busalacchi and Picaut [1983].

contributions to be a dominating factor in establishing the oceanic structure south of the Guinea dome. The most interesting results from the study of Philander and Pacanowski [1986] relevant to our observations in the following are features revealed by their mapping of heat storage in the
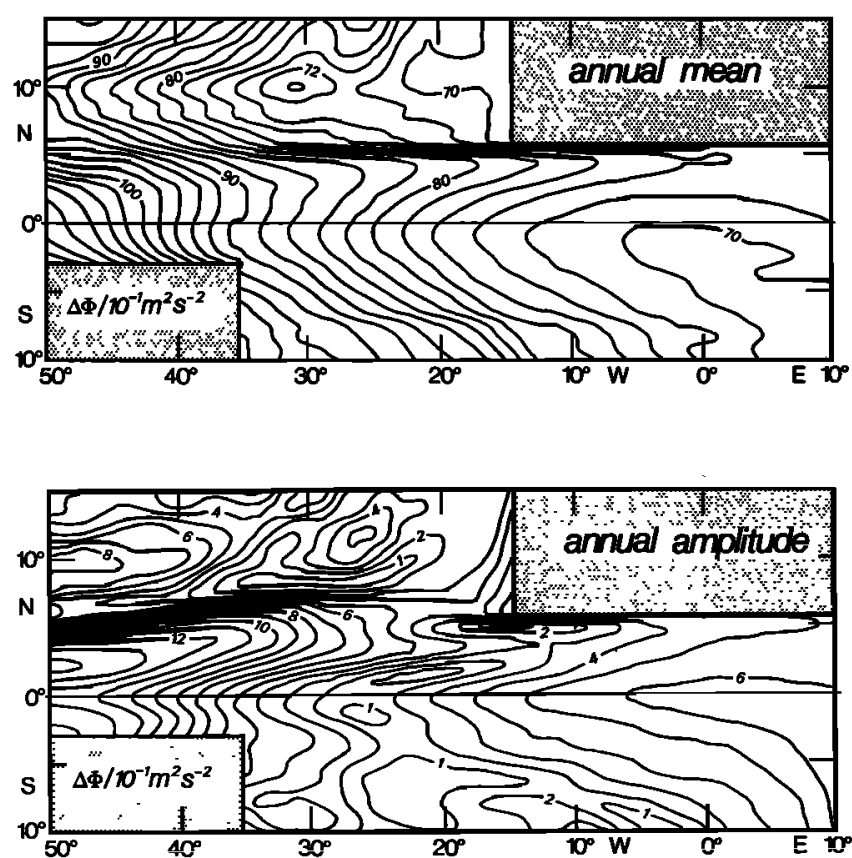

Fig. 6. Annual mean and amplitude of the annual cycle of geopotential anomaly at the sea surface relative to $500 \mathrm{dbar}$ after the model of Du Penhoat and Treguier [1984].
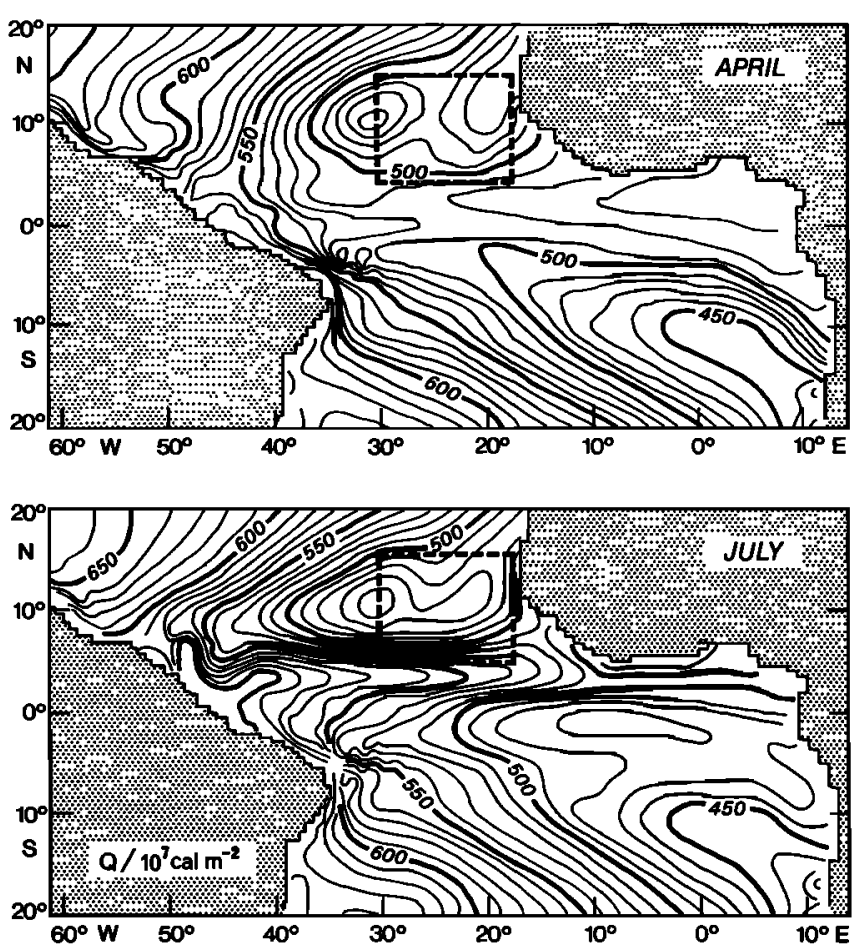

Fig. 7. Heat content $Q$ in the upper $317 \mathrm{~m}$ with the temperature reference $0^{\circ} \mathrm{C}$ in April and July from the model results of Philander and Pacanowski [1986]. The dashed box indicates the present study region.

upper ocean: A doming in the thermocline reduces the heat content in the upper water column, resulting in a heat storage minimum. Their fields of upper layer heat content are shown in Figure 7. A double-cell minimum is evident at latitudes of $10^{\circ}-12^{\circ} \mathrm{N}$, with the eastern part of the double-cell structure being in the area of the Guinea dome near $20^{\circ} \mathrm{W}$.

In the present study we determine the mean thermohaline structure and seasonal variability of the Guinea dome from observational data and then compare these results with those from a tropical Atlantic circulation model. The geographic area of our data-model comparison is shown in Figures 7 and 8.

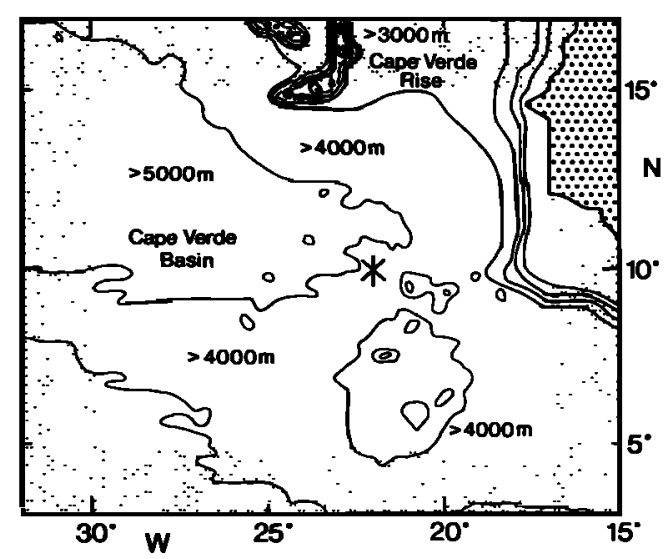

Fig. 8. Area of data-model comparison (unshaded box). The approximate location of the Guinea Dome is indicated by an asterisk. 


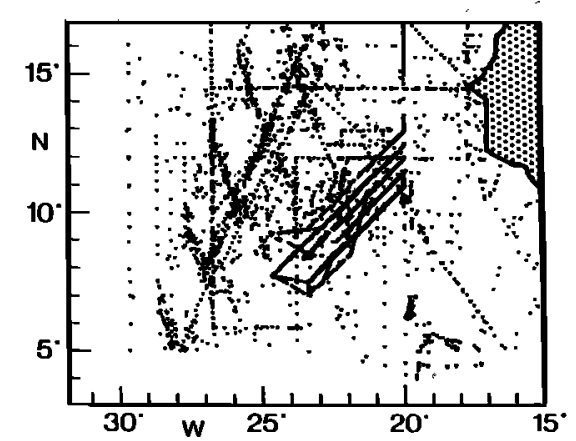

Fig. 9. Positions of stations included in our data set.

\section{The Data Set and Processing}

With the assistance of several international data centers we have assembled the oceanographic observations made at 2836 stations in the Guinea dome region. Their locations are shown in Figure 9; all were made between 1972 and 1987. This data set consists of three types of measurements: Most are from expendable bathythermograph (XBT) casts reaching maximum depths of either $450 \mathrm{~m}$ or $750 \mathrm{~m}$, depending on type of XBT, whereas the others come from conductivitytemperature-depth (CTD) measurements of temperature and salinity, and from Nansen bottle samples.

In order to determine the mean spatial structure and seasonal variability in the Guinea Dome region, the basic data set is divided into four seasonal subsets. The definition of the four seasons (Table 1) is based on characteristic features of the surface current system as observed from historical ship drift data [Richardson and McKee, 1984] and the monthly wind climatology given by Hastenrath and Lamb [1977]. The number of temperature and salinity profiles in the seasonal subsets are listed in Table 2. Because the horizontal data coverage in the area of investigation is too sparse for a detailed analysis in spring and autumn, we restrict our analysis to the summer and winter seasons. A $1^{\circ} \times 1^{\circ}$ grid is used for spatial averaging.

Our data processing consists of three stages. In the first we use only temperature profiles interpolated onto pressure surfaces separated by a uniform spacing of $5 \mathrm{dbar}$. Seasonal mean profiles with standard deviations, are calculated for all of the $1^{\circ} \times 1^{\circ}$ squares. We then compare all individual temperature profiles in each square on levels $5 \mathrm{dbar}$ apart
TABLE 2. Number of Profiles for the Seasons as Defined in Table 1

\begin{tabular}{lcc}
\hline & \multicolumn{2}{c}{ Number of Profiles } \\
\cline { 2 - 3 } Season & Temperature & Salinity \\
\hline Summer & 1538 & 925 \\
Autumn & 357 & 63 \\
Winter & 569 & 129 \\
Spring & 372 & 27 \\
\hline
\end{tabular}

with the seasonal mean profile for that square and eliminate those data cycles having values outside the limits of one standard deviation. From the remaining data set a new mean profile is calculated for each square, with the position of the derived profile being the average of those used. In about $5 \%$ of the total number of squares with data we were not able to obtain a reliable mean by this method at all levels. We then used the interpolated values from means of neighboring squares for certain levels. Squares in which we are able to derive representative profiles for the summer and winter seasons are displayed in Figure 10. Finally, the irregularly spaced mean profiles are then horizontally interpolated to the centers of the $1^{\circ} \times 1^{\circ}$, squares using objective analysis. The interpolation is done on each 5 dbar level down to 100 dbar, and from there down to $500 \mathrm{dbar}$ a vertical spacing of $10 \mathrm{dbar}$ is used. In order to check whether or not the high-density data set obtained during the GARP Atlantic Tropical Experiment (GATE) in 1974 on parallel southwestnortheast sections (see Figure 9) had a biasing effect, the procedure was repeated with only one mean GATE profile per $1^{\circ} \times 1^{\circ}$ square. No significant changes resulted in the mean fields.

Our second stage in data processing deals with the calculation of mean temperature-salinity $(T-S)$ curves in order to determine density from temperature. The geographical distribution of stations having both temperature and salinity data is not uniform through our study area; there is a greater data density in the eastern part of the area than in the west. Furthermore, most of the summer data are found between $5^{\circ} \mathrm{N}$ and $11^{\circ} \mathrm{N}$, and most of the winter data are between $9^{\circ} \mathrm{N}$ and $15^{\circ} \mathrm{N}$. This region is located to the south of the boundary separating the North and South Atlantic Central waters (NACW, SACW) as described by Sverdrup et al. [1942],

TABLE 1. Climatology and Currents During Seasonal Periods Chosen for the Analysis

\begin{tabular}{|c|c|c|}
\hline Season & Climatology & Surface Zonal Current \\
\hline Summer (June-Sept) & $\begin{array}{l}\text { ITCZ at about } 10^{\circ} \mathrm{N} \text { in Guinea } \\
\text { dome region. Weak winds of } \\
1-3 \mathrm{~m} \mathrm{~s}^{-1}\end{array}$ & $\begin{array}{l}\text { Eastward flowing NECC east of } \\
30^{\circ} \mathrm{W} \text {. Maximum development } \\
\text { of NECC in August. }\end{array}$ \\
\hline Autumn (Oct.-Nov.) & $\begin{array}{l}\text { ITCZ shifted equatorward. NE } \\
\text { trades reaching Guinea dome } \\
\text { region. }\end{array}$ & $\begin{array}{l}\text { Decreasing intensity and } \\
\text { northward extension of NECC. }\end{array}$ \\
\hline Winter (Dec.-Feb.) & $\begin{array}{l}\text { ITCZ near equator. Dome area } \\
\text { influenced by NE trades. Wind } \\
\text { speeds } 3-5 \mathrm{~m} \mathrm{~s}^{-1}\end{array}$ & $\begin{array}{l}\text { No eastward flow west of } 20^{\circ} \mathrm{W} \text {. } \\
\text { Year-round current to east } \\
\text { only east of } 20^{\circ} \mathrm{W} \text {. }\end{array}$ \\
\hline Spring (March-May) & $\begin{array}{l}\text { ITCZ moving north. Decreasing } \\
\text { influence of NE trades in } \\
\text { Guinea dome region. }\end{array}$ & $\begin{array}{l}\text { East of } 20^{\circ} \mathrm{W} \text {, currents flow east } \\
\text { into Gulf of Guinea. West of } \\
25^{\circ} \mathrm{W} \text { westward currents, most } \\
\text { intense in April-May at about } \\
40^{\circ} \mathrm{W} \text {. }\end{array}$ \\
\hline
\end{tabular}

ITCZ, Intertropical Convergence Zone; NECC, North Equatorial Countercurrent. 
Tomczak [1984], and Zenk et al. [1991]. The studies by Emery and Dewar [1982] and Siedler and Stramma [1983] show only small zonal variations of $T$-S characteristics in the Guinea dome region, but a clear change in the meridional direction occurs at about $10^{\circ} \mathrm{N}$. Our data coverage is not sufficient to check seasonal variations of $T$-S curves, so we are left with calculating mean curves and standard deviations for the two zonal bands of $5^{\circ}-10^{\circ} \mathrm{N}$ and $10^{\circ}-15^{\circ} \mathrm{N}$.

Determinations of derived quantities such as geopotential anomaly and geostrophic currents constitute the third stage of data processing. According to Siedler and Stramma [1983], the $T-S$ method provides better estimations of geopotential anomaly in this region from temperature profiles alone than does the use of mean vertical salinity profiles. Mean density profiles are constructed for each $1^{\circ} \times 1^{\circ}$ square for each season by using the appropriate seasonal mean temperature profiles and corresponding salinities from mean $T-S$ curves. The geopotential anomaly on different levels relative to $500 \mathrm{dbar}$ is then calculated for each square, and geostrophic flow patterns are determined from horizontal gradients.

\section{T-S Relationships and Water Mass Analysis}

Average $T-S$ curves for the two zonal bands of $10^{\circ}-15^{\circ} \mathrm{N}$ and $5^{\circ}-10^{\circ} \mathrm{N}$ are determined from our data set (Figure 11). They agree well with the earlier results of Emery and Dewar [1982]. As expected, SACW is the dominant water mass below a well-developed tropical thermocline, i.e., below approximately $60 \mathrm{~m}$. Below this depth the properties correspond to a mixture of SACW and NACW, with the percentage of NACW increasing with depth. Both curves exhibit a salinity minimum at approximately $S=34.65$ between $5^{\circ}$ and $6^{\circ} \mathrm{C}$, which is due to Antarctic Intermediate Water (AAIW). In the north, the core of the AAIW is saltier and lies at greater depth. The increase in salinity is caused by the mixing of AAIW with surrounding water masses along its
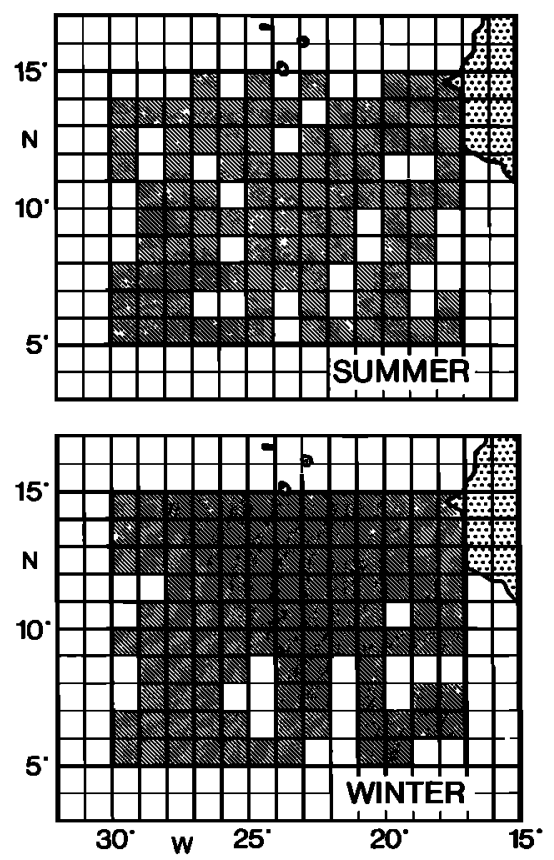

Fig. 10. The $1^{\circ} \times 1^{\circ}$ squares (shaded) in which mean temperature profiles have been derived for the summer and winter seasons.
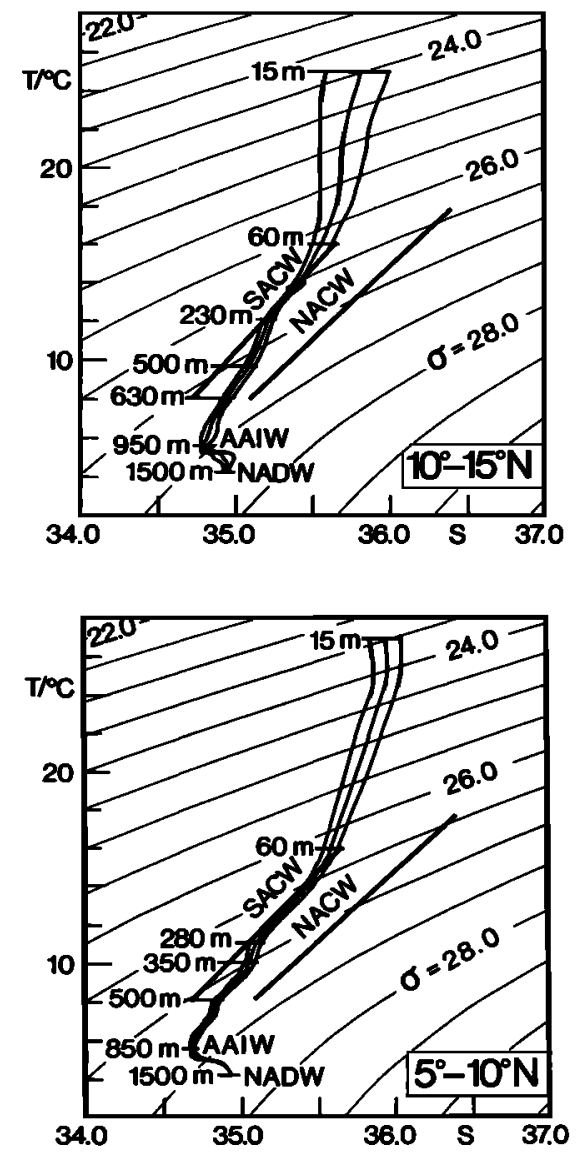

Fig. 11. Mean $T-S$ relations and standard deviation envelopes for the zonal bands of $10^{\circ}-15^{\circ} \mathrm{N}$ and $5^{\circ}-10^{\circ} \mathrm{N}$ in the area of observations. Significant features are marked with their depth. NACW, North Atlantic Central Water, SACW, South Atlantic Central Water, AAIW, Antarctic Intermediate Water, NADW, North Atlantic Deep Water. Heavy bars denote the mean relations for NACW and SACW from Sverdrup et al. [1942].

spreading path, whereas its deepening corresponds to an increasing vertical extent of the central water farther from the equator. The deepest water mass shown in the mean $T-S$ curves is the North Atlantic Deep Water (NADW), characterized by a salinity maximum at approximately $S=34.95$ and $T=4.0^{\circ} \mathrm{C}$. The southward deepening of the frontal zone separating SACW and NACW is evident from the increasing depth at which the mean $T-S$ curves start to deviate from the heavy line denoting the SACW. It changes from $230 \mathrm{~m}$ in the north to $280 \mathrm{~m}$ in south.

\section{THE Model}

The simulation is performed with a multilevel numerical model which was originally developed at the Laboratoire d'Océanographie Dynamique et de Climatologie (LODYC) by P. Delecluse's team [Chartier, 1985; Andrich et al., 1988] with the aim of providing an operational model with timevarying forcing. It is similar to the Geophysical Fluid Dynamics Laboratory (GFDL) model of Philander and Pacanowski [1986], but with differences in the grid and numerical codes used, the selection of conservative properties, the choices and implementation of buffer zones, and the wind forcing. The model solves the primitive equations which are slightly simplified by assuming hydrostatic equi- 
librium and by applying the Boussinesq and rigid lid approximations. The equations are solved on a Arakawa type " $\mathrm{C}$ ", grid [Arakawa, 1972] with a curvilinear formulation in the three spatial directions. Time stepping is achieved by a leapfrog scheme, with spurious time splitting being removed by an Asselin [1972] filter. The potential-enstrophyconserving finite-difference formulation given by Sadourny [1975] is fitted to the nonlinear terms of the momentum equation. The use of the $\mathrm{C}$ grid and enstrophy conservation are the major differences between this model and the GFDL model used by Philander and Pacanowski, [1986] which is formulated on a "B" grid and conserves energy. These properties were further discussed by Madec et al. [1991]. Density is calculated by a simplified nonlinear equation of state [Eckart, 1958]. Static instabilities arising from numerical integration are removed by a convective adjustment algorithm which ensures static stability at each time step.

A horizontal eddy mixing coefficient of $1 \times 10^{3} \mathrm{~m}^{2} \mathrm{~s}^{-1}$ (lower than $2 \times 10^{3} \mathrm{~m}^{2} \mathrm{~s}^{-1}$ in the GFDL model) is assumed for momentum, salinity, and temperature. Vertical eddy viscosity and eddy diffusivity coefficients are assumed to vary as a function of the local Richardson number $R \boldsymbol{i}$, similar to the parameterization of Pacanowski and Philander [1981]. They vary from the molecular temperature diffusivity $(1.34$ $\times 10^{-6} \mathrm{~m}^{2} \mathrm{~s}^{-1}$ ) to a maximum value of $10^{-2} \mathrm{~m}^{2} \mathrm{~s}^{-1}$ when $R i$ is zero.

The model domain extends west-east across the entire Atlantic and is closed by zonal boundaries at $30^{\circ} \mathrm{S}$ and $50^{\circ} \mathrm{N}$. The grid spacing is variable, with latitudinal resolution decreasing from $\frac{1}{3}^{\circ}$ at the zonal boundaries to $1^{\circ}$ in the interior, and a longitudinal resolution which varies from $\frac{1}{2}^{\circ}$ near the coasts to $1^{\circ}$ in the center of the basin. It should be noted that in the GFDL model the grid resolution is constant with respect to latitude $(33 \mathrm{~km})$ and longitude $(100 \mathrm{~km})$ between $10^{\circ} \mathrm{S}$ and $10^{\circ} \mathrm{N}$ and changes poleward from this region. This results in second-order accuracy between $10^{\circ} \mathrm{S}$ and $10^{\circ} \mathrm{N}$, but only first-order accuracy outside this region. In our model the grid spacing always ensures second-order accuracy. The model can thus be expected to provide a better simulation for the present study. In the Guinea dome area the longitudinal grid spacing is about $\frac{3}{4}^{\circ}$, and the latitudinal spacing varies from $\frac{1}{2}^{\circ}$ in the south to $1^{\circ}$ in the north.

We chose 16 vertical levels between the sea surface and $3750 \mathrm{~m}$ depth, and neither bottom topography nor islands are included. At boundaries, a no-slip condition and a damping zone are applied. A time step of $60 \mathrm{~min}$ is used.

The external forcing consists of heat flux and wind stress at the air-sea interface. The short- and long-wave components of the radiation budgets are taken from a monthly climatology given by Esbensen and Kushnir [1981]. Sensible and latent heat fluxes are computed with bulk formulas using air temperatures given by Esbensen and Kushnir [1981] and sea surface temperatures simulated by the model (for more details, see Morlière et al., [1989]). The wind field is that obtained from ship observations by G. Reverdin (personal communication, 1990) for the period of 1982-1984 and by Servain et al. [1987] for the period after 1984. They provide a monthly mean of pseudostress in $2^{\circ} \times 2^{\circ}$ squares between $30^{\circ} \mathrm{N}$ and $20^{\circ} \mathrm{S}$ east of $60^{\circ} \mathrm{W}$. Outside this area, the monthly climatology from Hellerman and Rosenstein [1983] is used, with wind stress fields being constructed through the use of drag coefficients computed according to Large and Pond
[1981] but modified by a stability dependence which results in increased stress in light wind conditions.

The initial conditions for the model are the monthly climatology for temperature and the annual climatology for salinity given by Levitus [1984]. During the simulation, the thermohaline structure changes according to model dynamics, but also according to a relaxation toward the Levitus [1984] monthly climatology for temperature and seasonal climatology for salinity. The aim is to minimize the effect of closed meridional boundaries at $30^{\circ} \mathrm{S}$ and $50^{\circ} \mathrm{N}$ by allowing climatological fluxes of mass and heat across these latitudes. For temperature, the inverse time constant $\gamma$ of the relaxation decreases with depth [Sarmiento and Bryan, 1982] and increases with latitude:

$$
\gamma=K\left[\gamma_{D}+\left(\gamma_{S}-\gamma_{D}\right) e^{-z / H}\right]
$$

where

$$
\begin{aligned}
K & =10^{-3}+1-\cos \phi \\
\phi & \quad \text { latitude } \\
\gamma_{D} & =1 / 720 \text { day }^{-1} \\
\gamma_{S} & =1 \text { day }^{-1} \\
z & \text { depth in meters; } \\
H & =200 \mathrm{~m} .
\end{aligned}
$$

The relaxation is thus negligible in the tropics. At the surface the relaxation terms begin to be significant $10^{\circ}$ off the equator. For salinity, the scheme is essentially the same except for the near-surface where an additional relaxation toward Levitus climatology is added at all latitudes with a 6-month time scale. The surface scheme applied to salinity is intended to compensate for unknown evaporation-precipitation imbalances and to prevent vertical mixing from causing unrealistic salinity increases in the upper layer such as those obtained in GFDL simulations [Wacongne, 1989].

For the purposes of modeling the tropical Atlantic on an operational basis [Merle and Morlière, 1988], a simulation was run from January 1, 1982, to the present. The main simulated parameters have been retained at each grid point at 5-day intervals, from which monthly means are computed for the period of 1982-1988 for temperature, salinity, velocity, and depths of the $15^{\circ}$ and $20^{\circ} \mathrm{C}$ isotherms [Morlière, 1989]. Results from this climatology are used to represent our simulation. This differs from the climatology of the tropical Atlantic presented by Philander and Pacanowski [1986], which was derived from a simulation of an ocean forced by the Hellerman and Rosenstein [1983] climatological winds.

\section{Temperature Distributions}

In the following we will compare observational and model results. Shown in Figures 12 and 13 are pairs of meridional and zonal temperature sections, respectively, for the summer and winter seasons. The left panel of each pair illustrates results from the objective analysis of observational data, whereas the results from the corresponding model simulation are shown on the right. As was noted in section 2, summer means come from the months of June to September, and winter means from the months of December to February.

A thermal doming is usually seen in both the observed and modeled sections below $50 \mathrm{~m}$. The observed summer sections indicate a strong isothermal doming in the upper 

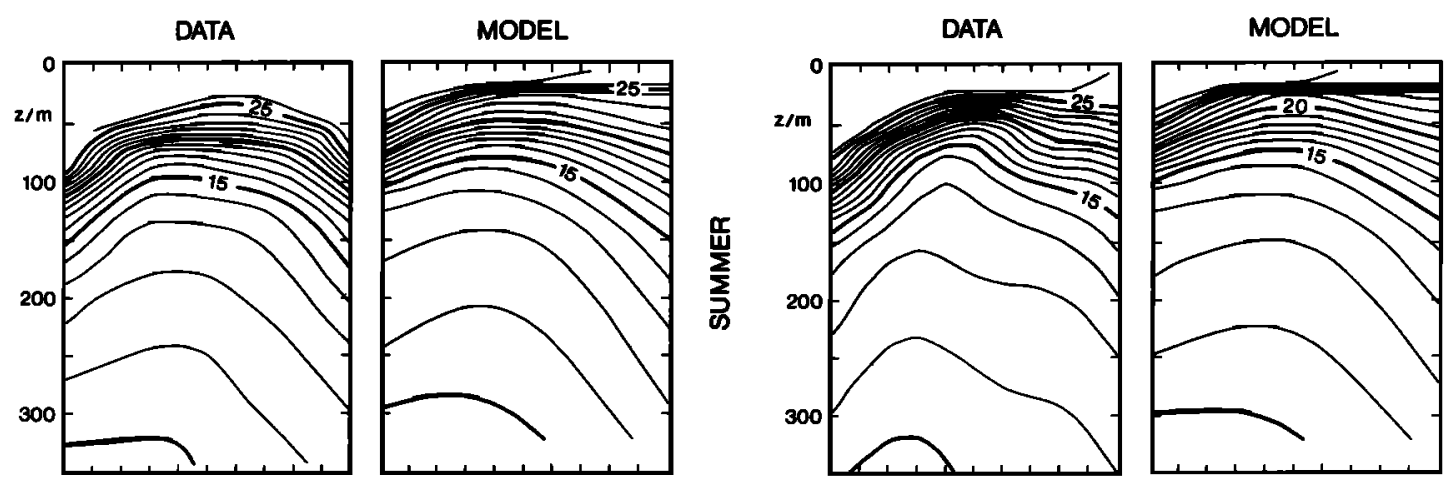

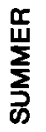
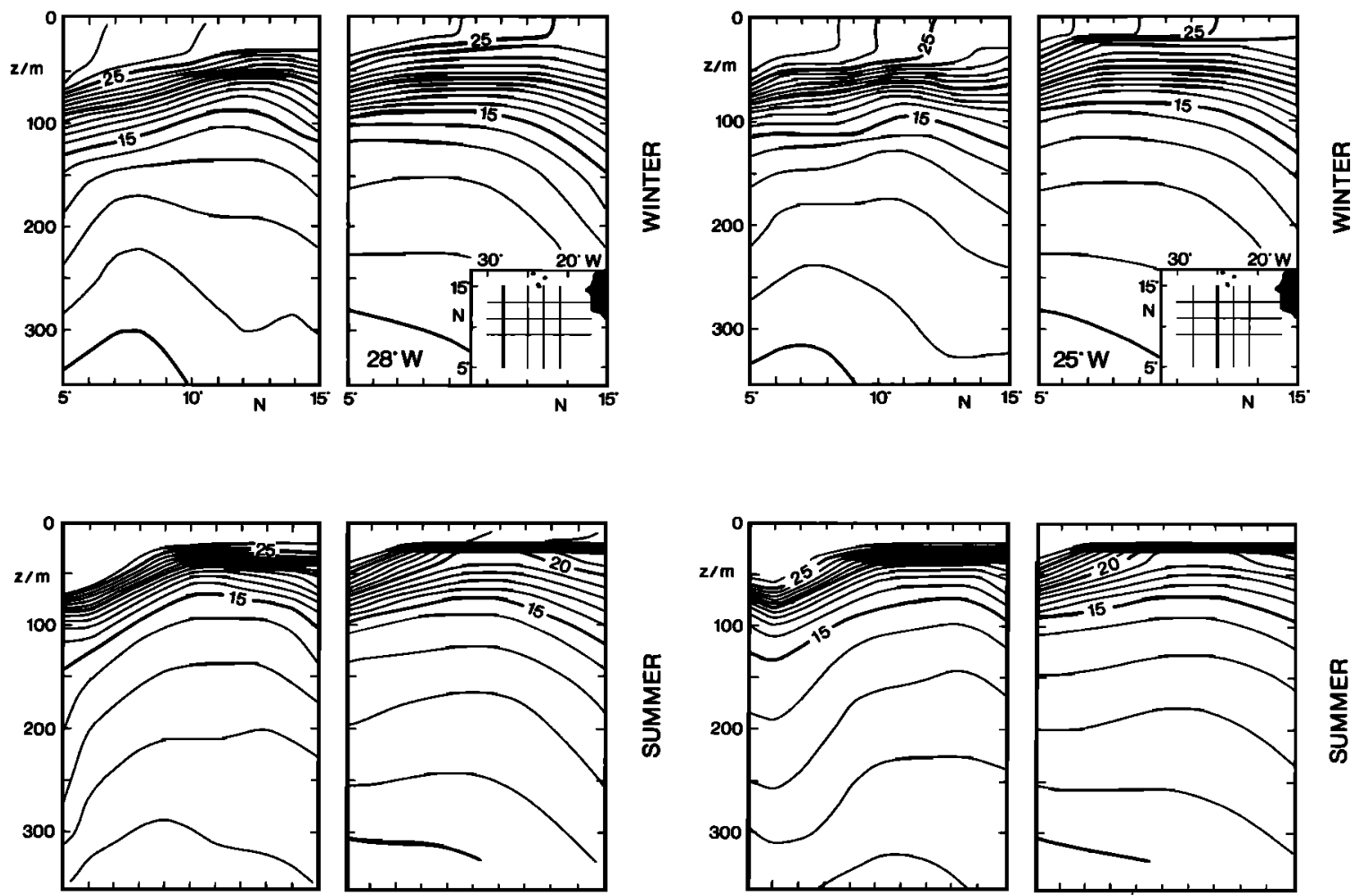

営
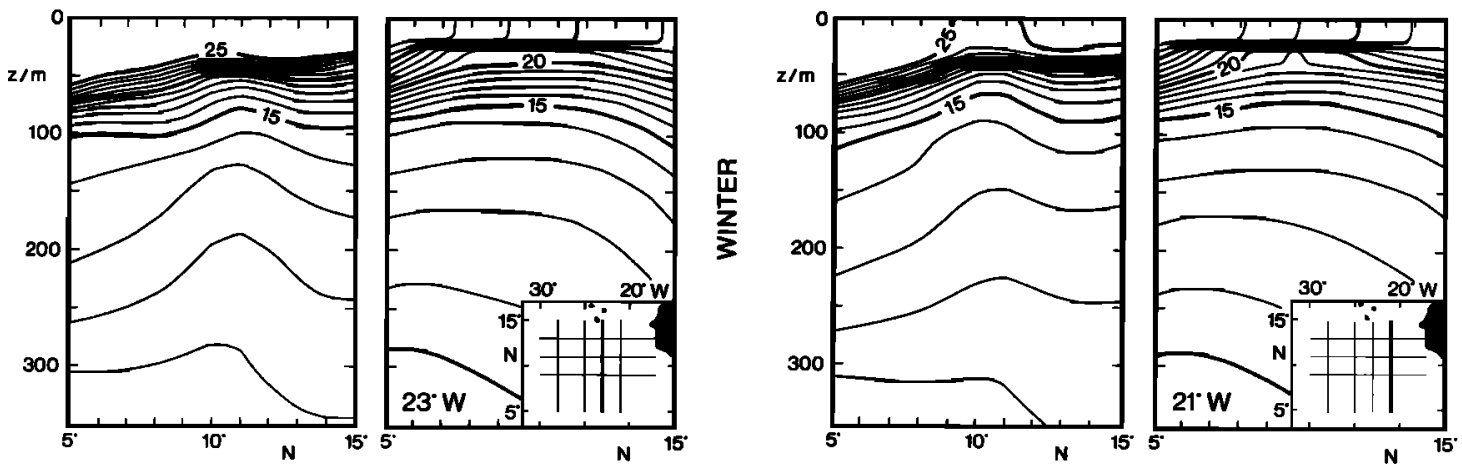

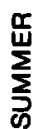

Fig. 12. Meridional temperature sections (degrees Celsius) derived from observations and model simulations. The location of each section is indicated in the respective inset.

thermocline (crests at 20 to $100 \mathrm{~m}$ ), similar magnitudes of vertical displacements in the intermediate thermocline (crests at 100 to $250 \mathrm{~m}$ ), and smaller magnitudes below. The axis of the dome is not vertical, but inclined to the south and west with increasing depth. In winter the Guinea dome is not well detected in the upper thermocline but has a signature of similar magnitude as in summer at greater depths with the same axis inclination. Maximum vertical isotherm displacements in the central part of the dome are approximately $80 \mathrm{~m}$ in the meridional and about $30 \mathrm{~m}$ in the zonal sections. The sections are generally consistent with the distributions observed by Hastenrath and Merle [1987], who, however, averaged over $2^{\circ}$ latitude $\times 4^{\circ}$ longitude, a much coarser resolution than with the $1^{\circ}$ squares used here. 

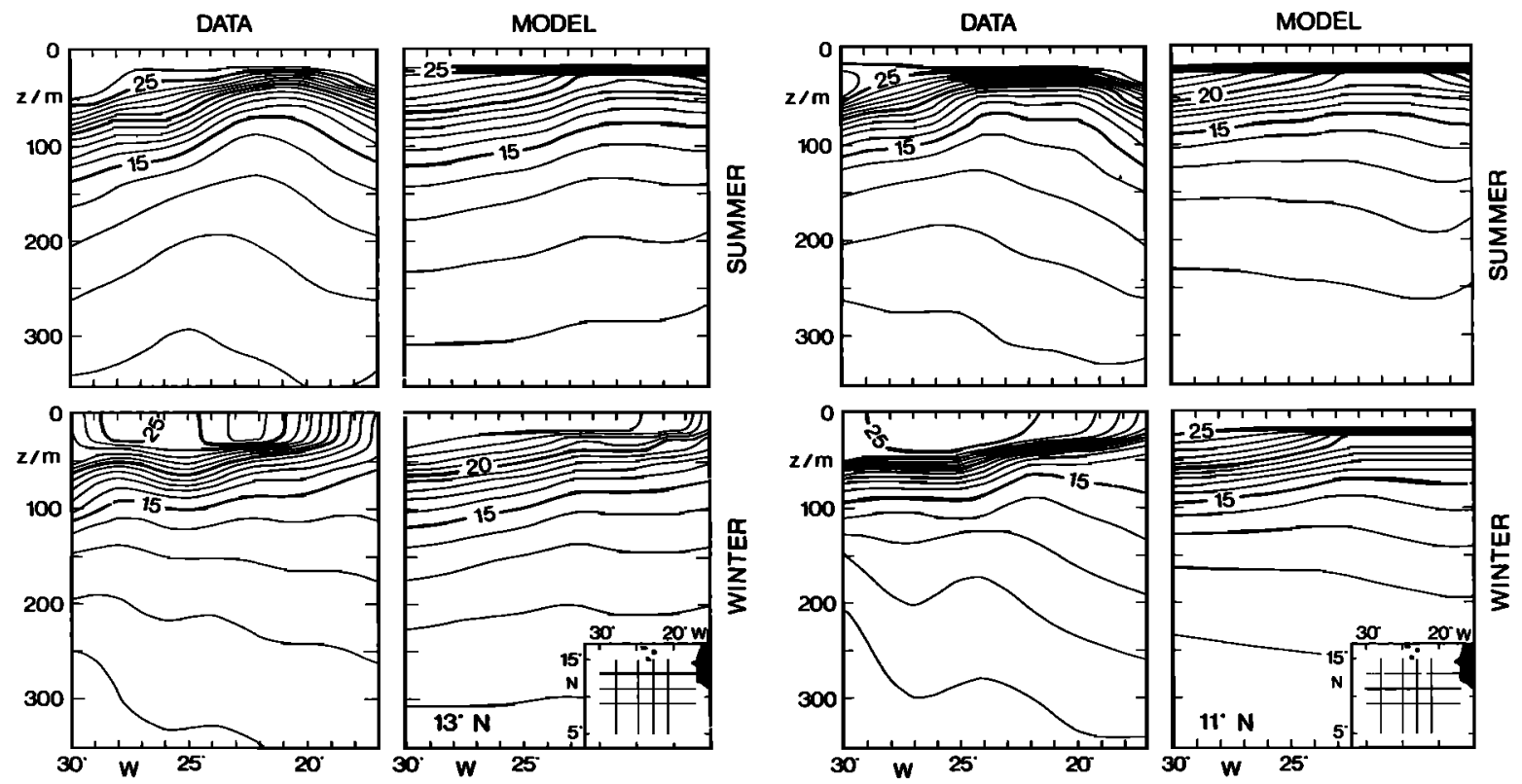
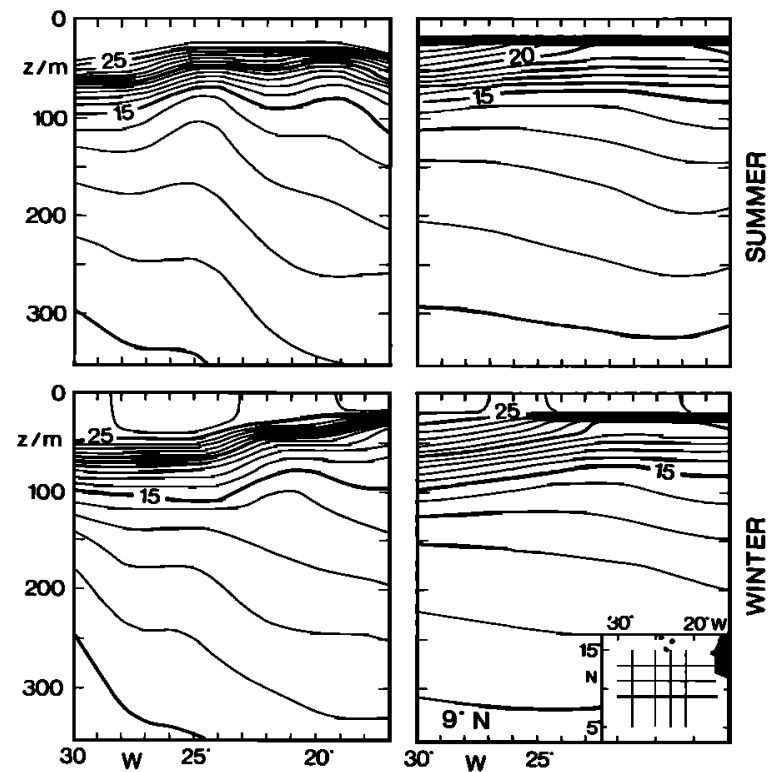

Fig. 13. Zonal temperature sections (degrees Celsius) derived from observations and model simulations. The location of each section is indicated in the respective inset.

The model sections indicate the dome to be at the same positions as do the data, with a corresponding vertical axis deflection and similar, although somewhat reduced, magnitudes of vertical displacements. A major deviation in vertical structure is found in the upper thermocline, where a sharper vertical gradient appears on top of a quasi-homogeneous layer in the model results. This will partly be the consequence of the differences in vertical resolution in the observations and the model. There are also some differences between the data and model in the shape of the isotherm doming, particularly in the deeper layers. In general, however, the agreement between the observational and simulated sections is clearly quite good.

Judging from the sections, the $15^{\circ} \mathrm{C}$ isotherm is a good indicator of the dome in both summer and winter. The depth distributions for this isotherm are presented in Figure 14, again in pairs of observational and model results. The observational maps display a predominantly zonal thermal ridge, with the Guinea dome being on the crest of the ridge in the eastern part. The thermal dome acts to increase the height of the ridge by about $30 \mathrm{~m}$, with the shape of the dome varying according to season. It is elongated in the southwestnortheast direction in summer, with a double-cell structure apparent in the observations, but not in the more smoothed model output. The structure is approximately circular in winter. It should be noted that the double-cell structure in Figure 14 is on a much smaller scale than the double cell apparent in Figure 7. There is also a definite change in the slope off the African coast in our results, with much stronger horizontal gradients in summer. The model results lead to a 

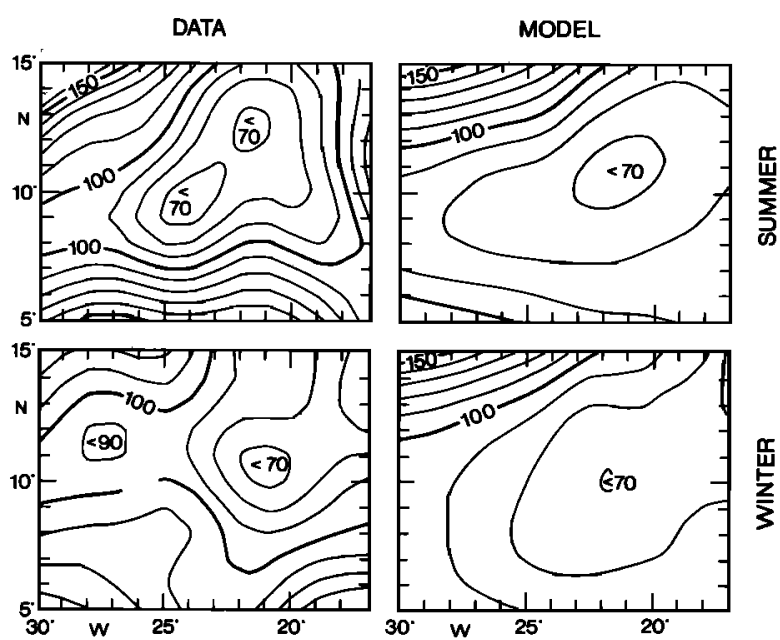

Fig. 14. Depth (meters) of the $15^{\circ} \mathrm{C}$ isotherm during summer and winter from observations and model simulations.

similar seasonal variation in the shape of the dome, though less pronounced and with somewhat smaller magnitudes of isotherm displacements.

There does not exist a sufficient number of salinity observations to adequately resolve the Guinea dome salinity structure with respect to either space or time. The model, however, includes the simulation of salinity fields. In Figure 15 , examples of the modeled temperature and salinity distributions along a meridional $\left(23^{\circ} \mathrm{W}\right)$ and zonal $\left(11^{\circ} \mathrm{N}\right)$ section through the center of the Guinea Dome are presented for one summer and one winter month (July and January). The temperature sections, as should be expected, are similar to the more smoothed sections in Figures 12 and 13. As in the temperature fields, the Guinea dome is clearly evident in the salinity distributions. An interesting feature that can now be seen is in the 30 - to $60-\mathrm{m}$ depth range: the subtropical salinity maximum. This water is generated by convective overturning in the central subtropics and, after subduction, is transported equatorward in the subtropical gyre [Defant, 1936; Bauer and Siedler, 1988]. The occurrence of the salinity maximum water to the north, west, and south of the Guinea dome can be explained either by a transition from the anticyclonic flow in the North Atlantic gyre to cyclonic motion in the west of the dome, or by an inflow of water from the western tropical Atlantic, with a source in the South Atlantic. The 25-m tritium map of Sarmiento et al. [1982] suggests the first interpretation.

\section{Geopotential Anomaly and Current Fields}

We will now determine the geostrophic flow fields associated with the thermal dome. Mean $T-S$ curves obtained from our analysis are used to calculate density in the pressure range of 50 to $500 \mathrm{dbar}$. The $50-\mathrm{m}$ level is always below the mixed layer in which thermohaline processes might change the $T-S$ relation, and the 500 -dbar level provides an approximate zero-current reference level corresponding to a lowvelocity depth range in Figure 3. The resulting density field is then used to determine the geopotential anomaly relative to $500 \mathrm{dbar}$. In order to judge the significance of the obtained anomaly distributions, it is necessary to estimate the errors and their possible effects on the flow field.

The geopotential anomaly is given by

$$
\Delta \phi=-\int_{p_{1}}^{p_{2}} \rho^{-1}(S, T, p) d p+\int_{p_{1}}^{p_{2}} \rho^{-1}(35,0, p) d p
$$

where $p_{1}$ and $p_{2}$ are the pressure limits for integration and $\rho$ is density. The second term is constant for fixed reference levels and will drop out when horizontal gradients are computed. In order to estimate errors in $\Delta \phi$, we assume a linear equation of state around some mean $S_{0}$ and $T_{0}$ and assume that pressure has little influence on $\rho$ in the layer
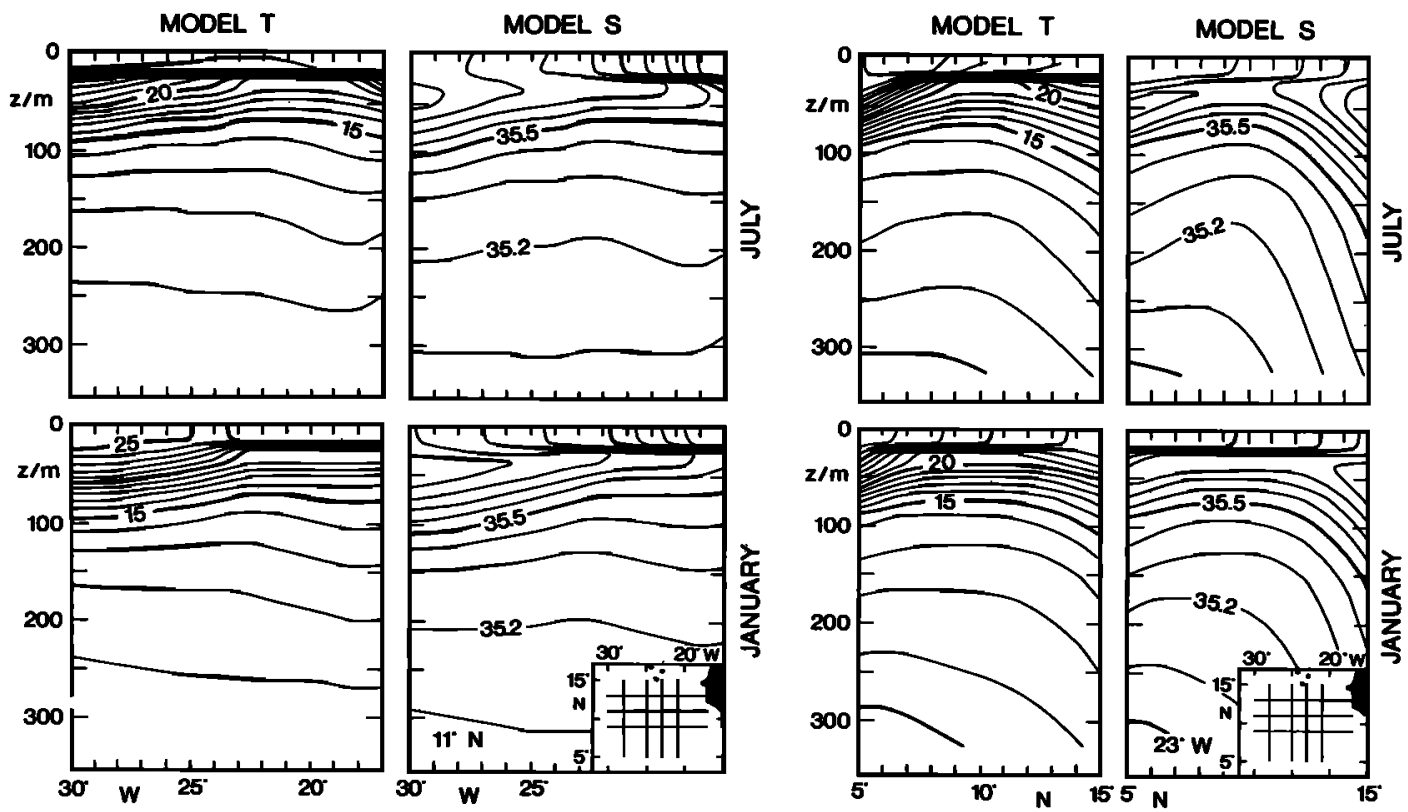

Fig. 15. Zonal $\left(11^{\circ} \mathrm{N}\right)$ and meridional $\left(23^{\circ} \mathrm{W}\right)$ sections of temperature $T$ (degrees Celsius) and salinity $S$ through the Guinea dome during July and January from model simulations. 


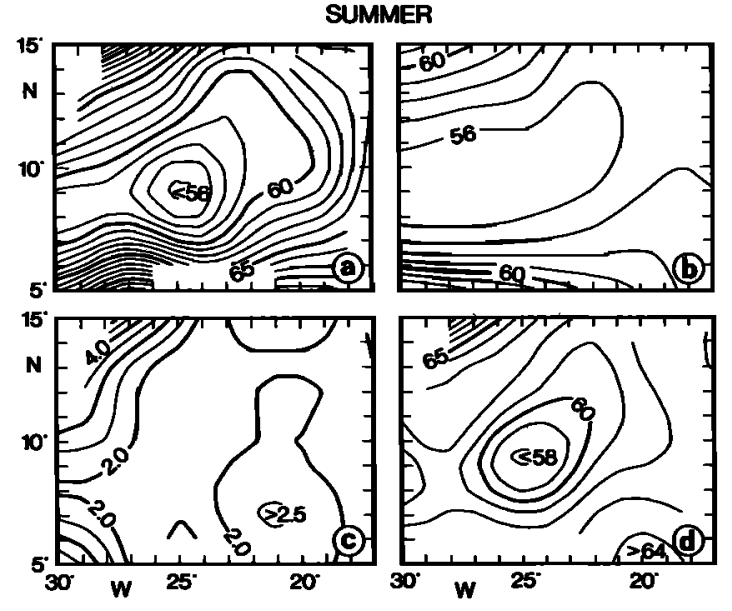

Fig. 16. Mean geopotential anomaly $\Delta \Phi$ (50 relative to $500 \mathrm{dbar}$ ) in $10^{-1} \mathrm{~m}^{2} \mathrm{~s}^{-2}$ during summer from $(a)$ observations and $(b)$ model simulations with (c) observational rms error $\Delta(\Delta \Phi)$ and $(d)$ the $\Delta \Phi$ field subjected to the "worst case" slope error (see text).

shallower than 500 dbar. The rms error $\Delta \rho$ is then approximated by

$$
\Delta \rho=\left[\left(\frac{\delta \rho}{\delta T} \Delta T\right)^{2}+\left(\frac{\delta \rho}{\delta S} \Delta S\right)^{2}\right]^{1 / 2}
$$

where

$$
\begin{aligned}
& \frac{\delta \rho}{\delta T}=\frac{\rho\left(S_{0}, T_{0}\right)-\rho\left(S_{0}, T_{0}-\Delta T\right)}{\Delta T} \\
& \frac{\delta \rho}{\delta S}=\frac{\rho\left(S_{0}, T_{0}\right)-\rho\left(S_{0}-\Delta S, T_{0}\right)}{\Delta S}
\end{aligned}
$$

This results in

$$
\begin{aligned}
\Delta \rho=\left\{\left[\rho\left(S_{0}, T_{0}\right)-\rho(\right.\right. & \left.\left.S_{0}, T_{0}-\Delta T\right)\right]^{2} \\
+ & {\left.\left[\rho\left(S_{0}, T_{0}\right)-\rho\left(S_{0}-\Delta S, T_{0}\right)\right]^{2}\right\}^{1 / 2} }
\end{aligned}
$$

The rms error $\Delta(\Delta \phi)$ of the geopotential anomaly is thus obtained by subtracting $\Delta \phi(\rho)$ from $\Delta \phi(\rho+\Delta \rho)$ :

$$
\Delta(\Delta \phi)=\int_{p_{1}}^{p_{2}}(\rho+\Delta \rho)^{-1} d p-\int_{p_{1}}^{p_{2}} \rho^{-1} d p
$$

$\Delta T$ is given by the standard deviation of mean temperaturedepth profiles. Since salinity-depth profiles had not been computed, we took $\Delta S$ from the standard deviation in the $T-S$ diagrams. The distributions of geopotential anomaly at 50 dbar relative to 500 dbar from observations and model simulations are presented in Figures $16 a$ and $16 b$ and in Figures $17 a$ and $17 b$, respectively. Because the geostrophic currents arise from horizontal gradients in geopotential anomaly, the significance of the obtained structures of the anomaly fields is tested by a "worst case" assumption: The error $\Delta(\Delta \phi)$ is added to all $1^{\circ} \times 1^{\circ}$ squares having $\Delta \phi$ values smaller than the average for the entire study area and subtracted from those squares having values larger than the area average. The error fields are given in Figures $16 c$ and $17 c$, and the resulting $\Delta \phi$ distributions from the "worst case" assumption are shown in Figures $16 d$ and $17 d$, respectively.

A pattern corresponding to cyclonic flow around the center of the Guinea dome is clearly seen in the mean observational $\Delta \phi$ maps. Horizontal gradients are stronger in summer than in winter, and even with the "worst case" assumption of reducing the slopes, the basic structure is well preserved. The model maps display a similar structure, with somewhat smaller magnitude of the doming.

From the geopotential anomaly fields we compute the geostrophic currents at the 50-dbar level (Figure 18). These have a circular pattern similar to the ones indicated by the isothermal depth distributions in Figure 14. Typical high speeds are $5-15 \mathrm{~cm} \mathrm{~s}^{-1}$. Strong northward velocities near the African coast are not found in winter as they are in summer; however, northward flow does exist farther off the coast in winter. Currents are generally stronger throughout summer than in winter, and a double-cell pattern is indicated in summer. The strengthening of the currents in summer in the south is consistent with the existence of the NECC in this season. The stronger currents in the north may be an indication of increased density gradients in the Cape Verde Frontal Zone [Zenk et al., 1991]. The 50-dbar currents from the model are presented in Figure 19. In comparing the maps in Figures 18 and 19, one has to remember that the model provides the sum of Ekman and geostrophic currents, while the observations lead to geostrophic currents only. At the surface, maximum Ekman velocities of up to $20 \mathrm{~cm} \mathrm{~s}^{-1}$ occur in January over the whole area. In July, such strong Ekman velocities can be found only in the southeastern corner (S. Arnault, personal communication, 1991). Thus at the 50-dbar level, which is close to the Ekman depth, the Ekman velocity is generally about $1 \mathrm{~cm} \mathrm{~s}^{-1}$ or less. If we subtract this amount from the model currents displayed in Figure 19, this might lead to local changes of the velocity field, but the general pattern will be preserved.

\section{ConClusions}

The present analysis provides improved information on the horizontal and vertical structure of the Guinea dome.

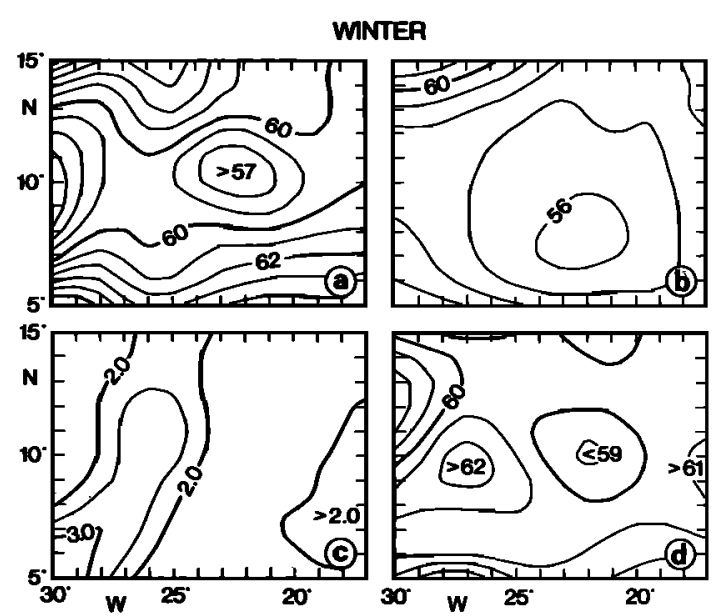

Fig. 17. Mean geopotential anomaly $\Delta \Phi(50$ relative to $500 \mathrm{dbar})$ in $10^{-1} \mathrm{~m}^{2} \mathrm{~s}^{-2}$ during winter from $(a)$ observations and $(b)$ model simulations with (c) observational rms error $\Delta(\Delta \Phi)$ and $(d)$ the $\Delta \Phi$ field subjected to the "worst case" slope error (see text). 

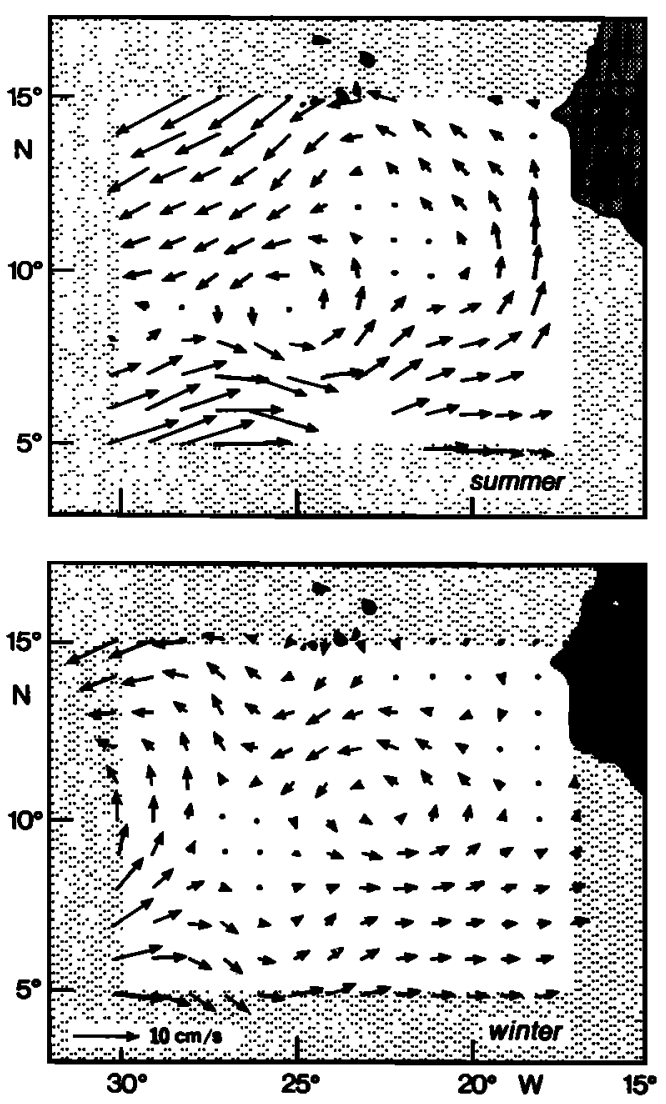

Fig. 18. Geostrophic currents at 50 dbar relative to 500 dbar during summer and winter from observations.

The earlier results by Voituriez [1981] and Hagen and Schemainda [1984] are confirmed: The Guinea dome is part of the zonal thermal ridge system in the northern tropical Atlantic and appears as a "mountain" on the eastern part of this ridge between the North Equatorial Current and the North Equatorial Countercurrent. It exists throughout the year at North Equatorial Undercurrent levels, while strong seasonal variations are found above.

The summer and winter mean distributions from our analysis give upward displacements of the thermocline and pycnocline of typically 30 to $80 \mathrm{~m}$ over horizontal scales of 700 to $1000 \mathrm{~km}$. The related geostrophic flow is cyclonic, with the rotational axis shifting to the southwest with increasing depth. The upper thermocline center of the dome is found at about $9^{\circ} \mathrm{N}, 25^{\circ} \mathrm{W}$, in summer and $10.5^{\circ} \mathrm{N}, 22^{\circ} \mathrm{W}$, in winter. These positions are not well defined, however, because of a double-cell structure apparent in the available data in summer. In winter the displacement of isotherms is strongly reduced in the uppermost part of the thermocline, but the displacement magnitude changes little in the thermocline below. The currents at 50-m depth are typically 5-10 $\mathrm{cm} \mathrm{s}^{-1}$, with the weaker flow occurring in winter. The major seasonal variation is found in the southern part of the dome, obviously related to the seasonal change in the North Equatorial Countercurrent.

The circulation model presented in our study better simulates the Guinea dome's structure than did earlier models. Observation and simulation give similar vertical and horizontal scales, with the model also indicating the seasonal variations found observationally: an elongation of the dome
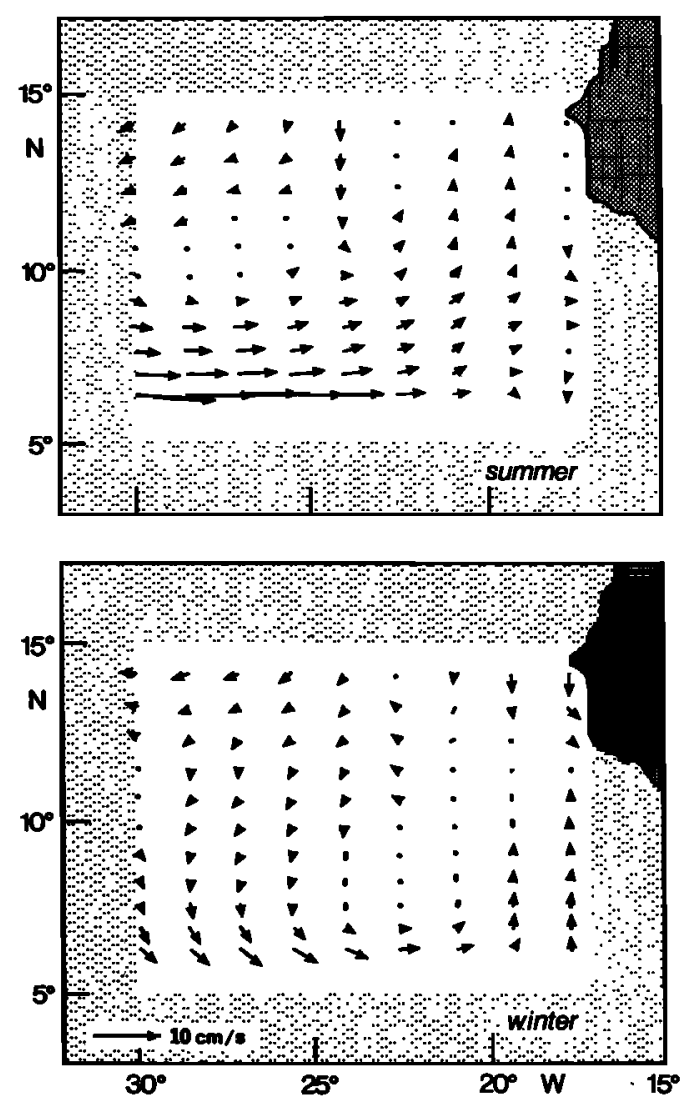

Fig. 19. Model currents at 50 dbar.

with a NE-SW orientation occurs in summer while a more circular shape is obtained in winter. Geopotential anomaly and geostrophic current fields are somewhat weaker in the model, but the structures of the fields are similar to those observed. Both the data and the model show a strongly increasing northward flow close to the African coast in summer. Also, seasonal changes in the salinity distributions can be obtained from the simulations. A haline doming is apparent, and a seasonal variation in the subtropical salinity maximum is found in the depth range immediately below the shallow mixed layer which extends to $20-50 \mathrm{~m}$.

The Guinea dome is part of the thermocline ridge extending across most of the tropical North Atlantic. Is the dome itself due to local or large-scale wind forcing? We cannot draw any final conclusion regarding that question from our analysis, but we will offer some suggestions. The wind stress curl maps of Hellerman and Rosenstein [1983] and Isemer and Hasse [1987] reveal the thermal ridge to be correlated with a zonal belt of positive annual mean curl. Hence the thermocline, along with cold and dense water from below, is lifted by Ekman suction. Extreme values of vertical Ekman velocity exceed $30 \mathrm{~m} \mathrm{yr}^{-1}$ [Leetmaa and Bunker, 1978], 60 $\mathrm{m} \mathrm{yr}^{-1}$ [Hellerman and Rosenstein, 1983], and $120 \mathrm{~m} \mathrm{yr}^{-1}$ [Isemer and Hasse, 1987]. Shown in Figure 20 is the distribution of mean vertical Ekman velocities obtained by Isemer and Hasse [1987]. A localized maximum of upward motion exists near the Guinea dome region. There is also a maximum of seasonal variability in Ekman suction in this area related to the meridional displacement of the Intertropical Convergence Zone (ITCZ). This is demonstrated by the 


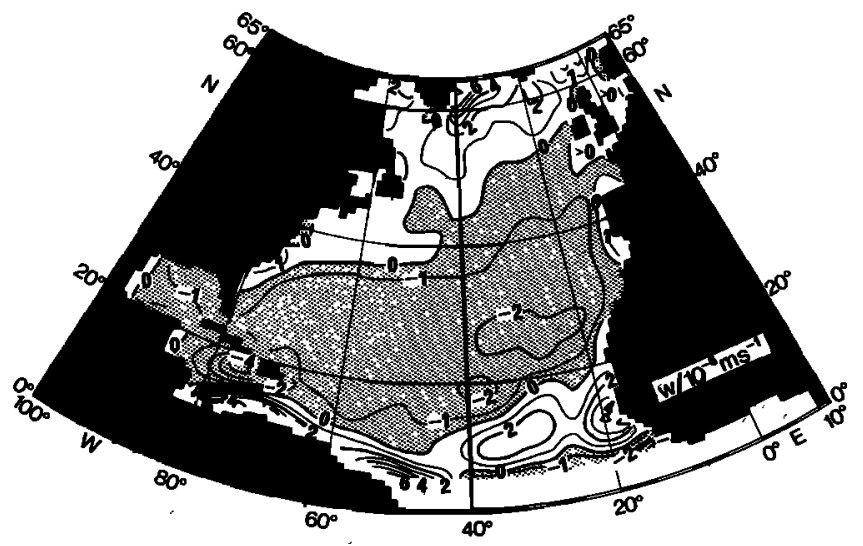

Fig. 20. Annual mean of vertical Ekman velocity in the North Atlantic after Isemer and Hasse [1987].

vertical Ekman velocity maps in Figure 21. The most vigorous upwelling occurs between July and October, when the ITCZ is found in the Guinea dome region and the NECC is at its strongest.

Voituriez [1981] compared the seasonal atmospheric pressure and wind fields in the eastern parts of the tropical Pacific and Atlantic. He concluded that the large-scale atmospheric fields are much more favorable in the Atlantic than in the Pacific to seasonal changes in the forcing. This is consistent with a year-round forcing of the Costa Rica dome by local winds [Hofmann et al., 1981] and with the large-
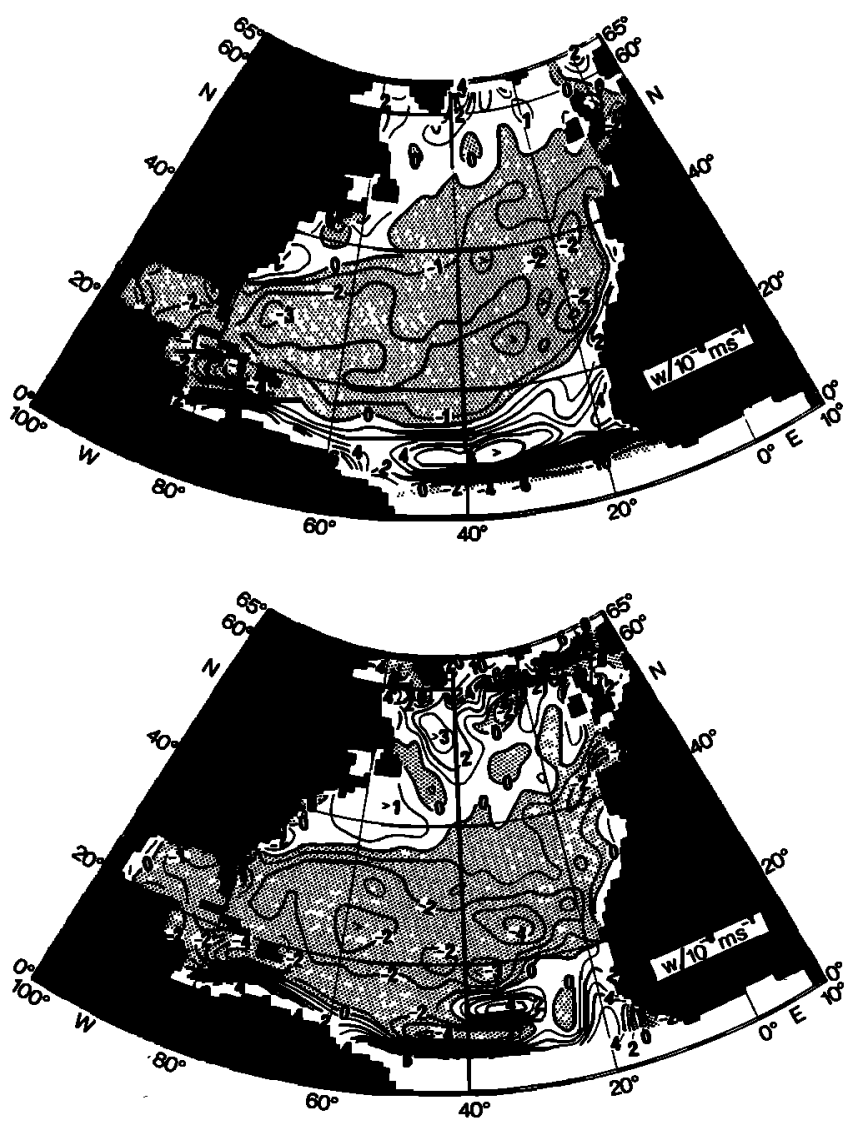

Fig. 21. Vertical Ekman velocity in the North Atlantic in (top) July and (bottom) January after Isemer and Hasse [1987]. scale wind forcing being more important in the Atlantic. However, in contrast to Voituriez [1981], who states that the Guinea dome in the thermocline exists only in summer, we do find the dome at $\mathbf{5 0}$ dbar also in winter, although smaller in horizontal extension and with weaker currents (Figure 18).

When comparing the smaller-scale features of the vertical Ekman velocity fields in Figures 20 and 21 with the results in Figures 16-19, we find them not well correlated. It is therefore likely that the Guinea dome is generated primarily not by local wind stress, but rather to a considerable extent by the large-scale wind stress field. This is consistent with the earlier conclusion of Busalacchi and Picaut [1983] that the Guinea dome is an approximately stationary feature because of the out-of-phase annual contributions of (local) Ekman pumping in the north and (nonlocally generated) equatorial waves in the south.

Bottom topography can be excluded as a major factor in generating the dome. Our model, contrary to earlier models such as Philander and Pacanowski [1980], assumes a flat bottom and yet provides an improved simulation of the Guinea dome. We believe that the large-scale wind stress forcing over many years used in our simulation is the most relevant factor in obtaining realistic temperature fields.

Acknowledgments. The authors want to thank B. Voituriez and E. Hagen for their help in obtaining the observational data and S. Arnault for providing the Ekman surface currents in the Guinea Dome area. We have also benefited from discussions on the tropical circulation with J. Merle. The following institutions were instrumental in assembling the data set: TOGA Tropical Subsurface Data Center, IFREMER, Brest; Bureau Informatique ORSTOM, Brest; Groupe PIRAL, Centre ORSTOM, Dakar; Institut für Meereskunde, Rostock-Warnemünde; and Deutsches Hydrographisches Institut, Hamburg. The collaboration between the French and German authors in this study was made possible by the stay of the first author as a visiting investigator at the Laboratoire d'Océanographie Dynamique et de Climatologie (LODYC), Université Pierre et Marie Curie, Paris. The assistance of the laboratory's director, $\mathrm{L}$. Merlivat, and her staff was much appreciated. Preparation of the manuscript was mostly done during the first author's stay as a visiting investigator at CIMAS, University of Miami. This institution's support is hereby acknowledged. We also want to thank R. G. Peterson and $\mathrm{S}$. Wacongne for their helpful comments on this paper. Funding for this work was provided by the Deutsche Forschungsgemeinschaft (SFB 133) and by ORSTOM.

\section{REFERENCES}

Andrich, P., G. Madec, and D. L'Hostis, Performance evaluation for an ocean general circulation model: Vectorization and multitasking, in Conference Proceeding of the International Conference on Supercomputing, pp. 295-303, AMC Press, St. Malo, France, 1988.

Arakawa, A., Design of the UCLA general circulation model, Numerical Simulation of Weather and Climate, Tech. Rep. 7, 116 pp., Dep. of Meteorol., Univ. of Calif., Los Angeles, 1972.

Asselin, R., Frequency filter for time integrations, Mon. Weather Rev., 100, 487-490, 1972.

Bauer, E., and G. Siedler, The relative contributions of advection and isopycnical and diapycnical mixing below the subtropical salinity maximum, Deep Sea Res., 35, 811-837, 1988.

Bubnov, V. A., and V. D. Egorikhin, Study of water circulation in the tropical Atlantic, Deep Sea Res., Part A, 26, suppl. II, $125-136,1979$.

Busalacchi, A. J., and J. J. O'Brien, The seasonal variability in a model of the tropical Pacific, J. Phys. Oceanogr., 10, 1929-1951, 1980.

Busalacchi, A. J., and J. Picaut, Seasonal variability from a model of 
the tropical Atlantic Ocean, J. Phys. Oceanogr., 13, 1564-1588, 1983.

Chartier, M., Un modèle numérique tridimensionnel aux équations primitives de circulation générale de l'océan, thèse de doctorat, Univ. P. et M. Curie, Paris, 1985.

Cochrane, J. D., F. J. Kelly, Jr., and C. R. Olling, Subthermocline countercurrents in the western equatorial Pacific Ocean, J. Phys. Oceanogr., 9, 724-738, 1979.

Defant, A., Schichtung und Zirkulation des Atlantischen OzeansDie Troposphäre, Wiss. Ergeb. Dtsch. Atl. Exped. Meteor 192527, 6, part I, 289-411, 1936.

Du Penhoat, Y., and A. M. Treguier, Sea-surface dynamic height topography and the North Equatorial Countercurrent as inferred from a linear model, Geophys. Res. Lett., 11(8), 799-801, 1984.

Du Penhoat, Y., and A. M. Treguier, The seasonal linear response of the tropical Atlantic Ocean, J. Phys. Oceanogr., 15, 316-329, 1985.

Eckart, C., Properties of water, II, The equation of water and sea water at low temperatures and pressures, Am. J. Sci., 256, 225-240, 1958.

Emery, W. J., and J. S. Dewar, Mean temperature-salinity, salinitydepth and temperature-depth curves for the North Atlantic and the North Pacific, Prog. Oceanogr., 11, 219-305, 1982.

Esbensen, S. K., and V. Kushnir, The heat budget of the global ocean: An atlas based on estimates from marine surface observations, Rep. 29, 27 pp., Clim. Res. Inst., Oreg. State Univ., Corvallis, 1981.

Hagen, E., and R. Schemainda, Der Guineadom im ostatlantischen Stromsystem, Beitr. Meereskd., Heft 51, 5-27, 1984.

Hastenrath, S., and P. J. Lamb, Climatic Atlas of the Tropical Atlantic and Eastern Pacific Oceans, 97 charts, University of Wisconsin Press, Madison, 1977.

Hastenrath, S., and J. Merle, Annual cycle of subsurface structure in the tropical Atlantic Ocean, J. Phys. Oceanogr., 17, 1518-1538, 1987.

Hellerman, S., and M. Rosenstein, Normal monthly wind stress over the world ocean with error estimates, J. Phys. Oceanogr., 13, 1093-1104, 1983.

Hisard, P., J. Citeau, and A. Morlière, Le système des contrecourants equatorieux subsuperficiels, Permanence et extension de la branche sud dans l'océan Atlantique, Cah. ORSTOM Ser. Océanogr., 14, 209-220, 1976.

Hofmann, E., A. Busalacchi, and J. O'Brien, Wind generation of the Costa Rica dome, Science, 214, 552-554, 1981.

Isemer, H.-J., and L. Hasse, The Bunker Climate Atlas of the North Atlantic Ocean, vol. 2, Air-Sea Interactions, Springer-Verlag, New York, 1987.

Large, W. G., and S. Pond, Open ocean momentum flux measurements in moderate to strong winds, J. Phys. Oceanogr., 11, 324-336, 1981.

Leetmaa, A. L., and A. F. Bunker, Updated charts of the mean annual wind stress, convergences in the Ekman layers, and Sverdrup transports in the North Atlantic, J. Mar. Res., 36, 311-322, 1978.

Levitus, S., Annual cycle of temperature and heat storage in the world ocean, J. Phys. Oceanogr., 14, 727-746, 1984.

Madec, G., M. Chartier, P. Delecluse, and M. Crépon, A threedimensional numerical study of deep water formation in the north western Mediterranean Sea, J. Phys. Oceanogr., in press, 1991.

Mazeika, P. A., Thermal domes in the eastern tropical Atlantic Ocean, Limnol. Oceanogr., 12, 537-539, 1968.

McPhaden, M. J., On the dynamics of equatorial subsurface countercurrents, J. Phys. Oceanogr., 14, 1216-1225, 1984.

Merle, J., and S. Amault, Seasonal variability of the surface dynamic topography in the tropical Atlantic Ocean, J. Mar. Res. 43, 267-289, 1985.

Merle, J., and A. Morlière, Toward an operational three- dimensional simulation of the tropical Atlantic Ocean, Geophys. Res. Lett., 15(7), 653-656, 1988.

Morlière, A., Climatologie d'une simulation de l'Atlantique tropical, Rapp. Interne LODYC T14, Lab. d'Océanogr. Dyn. et de Climatol., Univ. P. et M. Curie, Paris, Nov. 7, 1989.

Morlière, A., P. Delecluse, P. Andrich, and B. Camusat, Evaluation des champs thermiques simulés par un modèle de circulation générale de l'Atlantique tropical, Oceanol. Acta, 12(1), 9-22, 1989.

Pacanowski, R., and S. G. H. Philander, Parametrization of vertical mixing in numerical models of tropical oceans, J. Phys. Oceanogr., 11, 1443-1451, 1981.

Philander, S. G. H., and R. C. Pacanowski, The generation of equatorial currents, J. Geophys. Res., 85(C2), 1123-1136, 1980.

Philander, S. G. H., and R. C. Pacanowski, A model of the seasonal cycle in the tropical Atlantic Ocean, J. Geophys. Res., 91(C12), 14,192-14,206, 1986.

Richardson, P. L., and T. K. McKee, Average seasonal variation of the Atlantic equatorial currents from historical ship drifts, $J$. Phys. Oceanogr., 14, 1226-1238, 1984.

Rossignol, M., and A. M. Meyruis, Campagnes océanographiques du Gérard-Tréca, 53 pp., Cent. Oceanogr. Dakar-Thiaroye, ORSTOM, Dakar, Senegal, 1964.

Sadourny, R., The dynamics of finite-difference models of the shallow-water equations, J. Atmos. Sci., 32, 680-689, 1975.

Sarmiento, J. L., and K. Bryan, An ocean transport model for the North Atlantic, J. Geophys. Res., 87(C1), 394-408, 1982.

Servain, J., M. Seva, S. Lukas, and G. Rougier, Climatic atlas of the tropical Atlantic wind stress and sea surface temperature: 19801984, Ocean Air Interact., 1, 109-182, 1987.

Siedler, G., and L. Stramma, The applicability of the $T / S$ - method to the geopotential anomaly computations in the northeast Atlantic, Oceanol. Acta, 6, 167-172, 1983.

Sverdrup, H. U., M. W. Johnson, and R. H. Fleming, The oceans: Their Physics, Chemistry and General Biology, 1087 pp., Prentice-Hall, Englewood Cliffs, N. J., 1942.

Tomczak, M., Jr., Ausbreitung und Vermischung der Zentralwassermassen in den Tropengebieten der Ozeane, 1, Atlantischer Ozean, Oceanol. Acta, 7, 145-158, 1984.

Tsuchiya, M., Subsurface countercurrents in the eastern equatorial Pacific Ocean, J. Mar. Res., 33, 145-175, 1975.

Tsuchiya, M., The origin of the Pacific equatorial $13^{\circ} \mathrm{C}$ Water, $J$. Phys. Oceanogr., 11, 794-812, 1981.

Voituriez, B., Les sous-courants équatoriaux nord et sud et la formation des dômes thermiques tropicaux, Oceanol. Acta, 4, 497-506, 1981.

Voituriez, B., and A. Herbland, Comparison des systèmes productifs de l'Atlantique tropical est: Dômes thermiques, upwellings côtiers et upwelling equatorial, Rapp. $P . V_{.}$, Reun. Cons. Int. Expl. Mer, 180, 114-130, 1982.

Wacongne, S., Dynamical regimes of a fully nonlinear stratified model of the Atlantic equatorial undercurrent, J. Geophys. Res., 94(C4), 4801-4815, 1989.

Wyrtki, K., Upwelling in the Costa Rica dome, Fish. Bull., 63, 355-372, 1964.

Zenk, W., B. Klein, and M. Schröder, Cape Verde Frontal Zone, Deep Sea Res., 38, suppl. 1, S505-S530, 1991.

A. Morlière, ORSTOM/LODYC, Tour 14, Université Pierre et Marie Curie, 4, place Jussieu, 75252 Paris Cedex 05, France.

R. Onken, G. Siedler, and N. Zangenberg, Abteilung Meeresphysik, Institut für Meereskunde, Universität Kiel, Düsternbrooker Weg 20, D-2300 Kiel, Germany.

(Received January 7, 1991; accepted May 8, 1991.) 